\title{
High Temperature Metal Hydrides as Heat Storage Materials for Solar and Related Applications
}

\section{Michael Felderhoff * and Borislav Bogdanović}

Max-Planck Institut für Kohlenforschung, Kaiser-Wilhelm-Platz 1, 45470 Mülheim /Ruhr, Germany

* Author to whom correspondence should be addressed; E-Mail: felderhoff@mpi-muelheim.mpg.de; Tel. +49 (0)208306 2458

Received: 28 November 2008; in revised form: 8 January 2009 / Accepted: 13 January 2009 /

Published: 15 January 2009

\begin{abstract}
For the continuous production of electricity with solar heat power plants the storage of heat at a temperature level around $400{ }^{\circ} \mathrm{C}$ is essential. High temperature metal hydrides offer high heat storage capacities around this temperature. Based on $\mathrm{Mg}$ compounds, these hydrides are in principle low-cost materials with excellent cycling stability. Relevant properties of these hydrides and their possible applications as heat storage materials are described.
\end{abstract}

Keywords: Hydrogen storage, heat storage, magnesium hydride, $\mathrm{Mg}_{2} \mathrm{FeH}_{6}$.

\section{Introduction}

The paper on hand deals with a chemical-based method for thermal solar energy storage. Materials which are appropriate for this purpose are chemical compounds of metals, metal alloys or intermetallic compounds and hydrogen known as metal hydrides $\left(\mathrm{MH}_{\mathrm{n}}\right.$, Equation 1). The majority of metals, metal alloys and intermetallic compounds react directly with gaseous hydrogen (Equation 1 from left to right) to form metal hydrides in an exothermal way, that is, with release of heat $(\Delta H)$. If the formation of a metal hydride under certain conditions is a reversible reaction ( $\longleftrightarrow$ ), then the metal hydride can by a heat supply upon decomposition into the metal and hydrogen. Upon thermal dissociation of a 
metal hydride by heat absorption (Equation 1, from right to left), the thermal energy is transformed into chemical energy. Expressed in another way: thermal energy can be reversibly stored as the heat of reaction of reversible chemical reactions. Among the methods for heat storage, sensible and thermochemical heat storage, the thermochemical method offers in general the higher amount of energy stored per mass of storage material (Table 1) [1,2].

Table 1. Frequently used solid and liquid materials for the storage of sensible heat [1].

\begin{tabular}{|c|c|c|c|c|}
\hline & $\begin{array}{l}\text { M.p. } \\
{\left[{ }^{\circ} \mathbf{C}\right]}\end{array}$ & $\begin{array}{c}\text { Temperature range } \\
{\left[{ }^{\circ} \mathbf{C}\right]}\end{array}$ & $\begin{array}{c}\rho \\
{\left[\mathrm{g} \mathrm{cm}^{-3}\right]}\end{array}$ & $\begin{array}{c}c \\
{\left[\mathrm{~kJ} \mathrm{~kg}^{-1} \mathbf{K}^{-1}\right]}\end{array}$ \\
\hline Water & 0 & $0-100$ & 0.98 [a] & 4.19 \\
\hline Thermo-oil & $-70 /-10$ & up to $350[\mathrm{~b}]$ & $0.87[\mathrm{a}]$ & 2.1 \\
\hline $\begin{array}{c}53 \mathrm{KNO}_{3} / 40 \mathrm{NaNO}_{2} / \\
7 \mathrm{NaNO}_{3}[\mathrm{c}]\end{array}$ & 142 & up to 450 & $1.85[\mathrm{a}]$ & 1.3 \\
\hline $\mathrm{Na}$ & 98 & & 0.84 [d] & 1.26 \\
\hline Cast iron & $1150-1300$ & & $7.2[\mathrm{~d}]$ & 0.54 \\
\hline Aluminium & 660 & & 2.7 [d] & 0.92 \\
\hline Fire clay & & & $2.1-2.6[\mathrm{~d}]$ & 1.0 \\
\hline $\mathrm{Al}_{2} \mathrm{O}_{3}$ & 1700 & & $3.0[\mathrm{~d}]$ & 1.0 \\
\hline $\mathrm{MgO}$ & 1700 & & $3.0[\mathrm{~d}]$ & 1.0 \\
\hline Stone & & & $1.9-2.6[\mathrm{~d}]$ & $0.8-0.9$ \\
\hline Concrete & & & & 0.9 \\
\hline
\end{tabular}

[a] Average density in the temperature range given, [b] some thermooils can be used up to $390{ }^{\circ} \mathrm{C}$,

[c] wt.\%, [d] at room temperature.

The special feature of metal hydrides as reversible heat storage systems is that upon their thermal dissociation the liberated hydrogen is simultaneously a fuel with the highest known gravimetric energy density (usually expressed in $\mathrm{MJ} \cdot \mathrm{kg}^{-1}$ ). The gravimetric energy density of hydrogen $[1,3]$ is about three times higher than that of gasoline. Hydrogen in liquid form is therefore used as a rocket fuel. A further remarkable feature of hydrogen as a fuel is that upon its combustion at high temperatures in air [4] as well as upon "cold combustion" in low temperature fuel cells, only pure water is produced. Thus, from ecological standpoint hydrogen is an ideally clean, albeit a secondary energy carrier. The last attribute means that hydrogen has first to be produced under consumption of primary energy sources which are at present primarily fossile fuels or, otherwise, nuclear energy (via water electrolysis) or, in the future, the expected solar energy. From the above statements it follows that the reversible metal hydride/metal systems (Equation 1) are to be considered as energy carriers in a double sense - namely as heat and as hydrogen storage systems.

$$
\begin{gathered}
\mathrm{M}+\mathrm{n} / 2 \mathrm{H}_{2} \underset{\text { heat absorption (heat storage) }}{\stackrel{\text { heat evolution (heat recovery) }}{\longleftarrow}} \mathrm{MH}_{\mathrm{n}}+\Delta \mathrm{H} \\
\mathrm{M}=\text { metal, metal alloy, intermetallic compound }
\end{gathered}
$$


In the heat storage application, the heat of reaction liberated in the hydride formation process serves as useful heat. Thereby hydrogen is confined in a closed system and is preserved during a great number of heat storage cycles. In the other case - as a hydrogen store - the hydrogen liberated from the hydride is present in an open system, and after displacement from the hydride it is irreversibly burned to water.

\section{The principle of heat and hydrogen storage by the $\mathrm{MgH}_{2} / \mathrm{Mg}$ system}

The magnesium hydride/magnesium system is particularly suitable for both purposes, because in $\mathrm{MgH}_{2}$ the reversible hydrogen storage capacity is the highest among reversible binary hydrides (7.6 wt.\%) and because upon the reaction of magnesium with hydrogen (Equation 2) a relatively large amount of heat $\left(75 \mathrm{~kJ} \cdot \mathrm{mol}^{-1} \mathrm{H}_{2},\left(0.9 \mathrm{kWh} \mathrm{kg}{ }^{-1} \mathrm{Mg}\right)\right.$ at a temperature level between $\approx 200$ and $500{ }^{\circ} \mathrm{C}$ is set free. Herewith an extremely important region for heat storage becomes available, since according to the Carnot principle, heat energy at this level can be transformed with high efficiency into other energy forms like mechanical energy and hence in electricity. We are dealing here mainly with the application of magnesium hydride as a heat storage medium. The $\mathrm{MgH}_{2} / \mathrm{Mg}$ system (Equation 2), however, can also be applied for hydrogen storage. Upon gradually heating up of $\mathrm{MgH}_{2}$ in a closed system the compound will dissociate giving $\mathrm{Mg}$ and $\mathrm{H}_{2}$ and the hydrogen pressure above the remaining $\mathrm{MgH}_{2}$ will increase exponentially following the van't Hoff law (Figure 1).

$$
\begin{aligned}
\mathrm{MgH}_{2}+75 \mathrm{~kJ} \mathrm{~mol}^{-1} & \underset{\text { heat recovery }}{\stackrel{\text { heat storage }}{\rightleftarrows}} \mathrm{Mg}+\mathrm{H}_{2} \\
\mathrm{~T} & =250-500{ }^{\circ} \mathrm{C}
\end{aligned}
$$

The knowledge of the $\mathrm{H}_{2}$ dissociation (equilibrium) pressure as a function of temperature is of fundamental importance for the operation of the $\mathrm{MgH}_{2}$ heat and hydrogen storage system. At a given $\mathrm{H}_{2}$ pressure the course of the curve in Figure 1 determines which minimal temperature that is definitely necessary in order to liberate the hydrogen from $\mathrm{MgH}_{2}$ under a given $\mathrm{H}_{2}$ pressure (f.i. $450{ }^{\circ} \mathrm{C}$ for 40 bar of $\mathrm{H}_{2}$ pressure); and conversely, upon charging of $\mathrm{Mg}$ with hydrogen under given pressure conditions the temperature of the store will correspond to the hydrogen charging pressure. Thus, by choice of the hydrogen pressure it is possible to determine at which temperature level the stored heat will be delivered. The diagram in the Figure 1 shows additionally under which temperature and pressure conditions the system will absorb or desorb heat (shaded part - heat absorption; clear part heat desorption). Although the diagram in the Figure 1 indicates under which conditions the reaction can go in one or in the other direction, it does not give any information if at all and how rapidly the reaction will take place. In the early [5] and in the more recent literature [6] it is often stated that the reaction of magnesium with hydrogen is notoriously sluggish and therefore hardly useful for heat storage [5]. For an optimal thermochemical heat storage material it is required that the chemical reaction be much more rapid than the rate of heat transport, so that the dynamics of the system will depend mainly on the rate of the heat transport. Additionally, it is required that the reaction in both directions is any times repeatable and that the material shows no sign of fatigue. For accelleration of 
chemical reactions, apart from increase of temperature, and the effect of the microstructure of particles [6], the general answer is catalysis.

Figure 1. Dissociation pressure curve of $\mathrm{MgH}_{2}$.

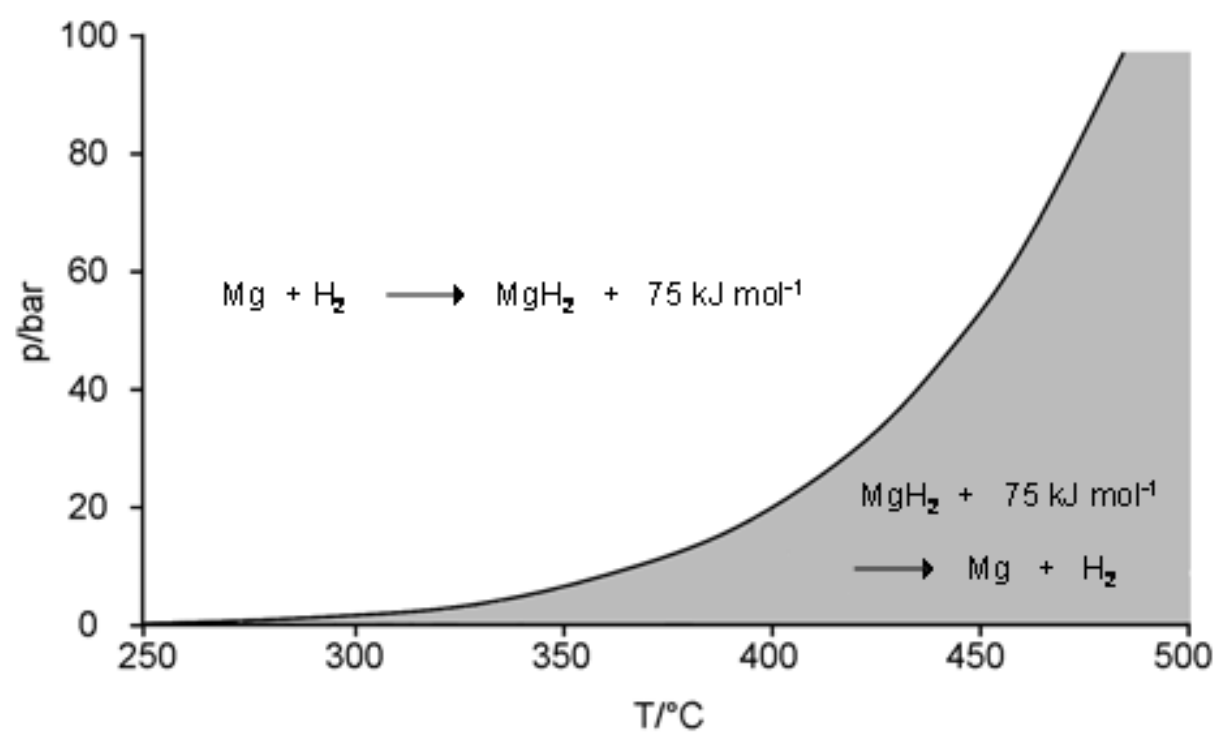

At the beginning of our research work on metal hydrides there was the experimental finding that the reaction of magnesium with hydrogen in solution can be catalyzed [7]. During the past years the research in this field has led to $\mathrm{MgH}_{2} / \mathrm{Mg}$ materials which fulfill the above mentioned criteria: satisfactory kinetics combined with stability upon cyclic hydrogen charging and discharging. The first method for the preparation of the so-called "active $\mathrm{MgH}_{2} / \mathrm{Mg}$ materials" (Equation 3) $[1,8]$ consists in treatment of commercial Mg powder (f.i. 270 mesh) with hydrogen in an organic solvent (i.e. toluene) in the presence of a small amount of the soluble organometallic nickel complex bis(cyclooctadiene1,5-Ni(0) [9] at ambient temperature and normal pressure. The Ni-complex is hereby instantaneously hydrogenated to cyclooctane and metallic nickel and the latter, in a fine dispersion, is precipitated on the surface of the $\mathrm{Mg}$ particles and acts as a catalyst for hydrogenation and dehydrogenation of the former. The second method [8] consists of intimately mixing of the Mg powder with 4-10 wt.\% of fine commercial Ni powder. The activity of the material prepared according to the second method is somewhat lower than that of the first method. Cycle stability of the "standard materials" is presented in Ref. [8] (Figures 4, 5 and 9 therein). The Mg powders doped with $\mathrm{Ni}$ in these ways and fabricated several times on a $10 \mathrm{~kg}$ scale were shown in numerous tests to be suitable materials for heat and hydrogen storage and were employed by us and by others in several storage installation prototypes [1, $8,10-12]$, three of which are presented in Section 3. Already after the first hydrogenation the materials are fully active and remain active during hundreds of hydrogen charging-discharging cycles. A more recent 1,000 cycle test using both materials is shown in Figure 2 [13]. Some restrictions at high temperatures are discussed further in Section 4.

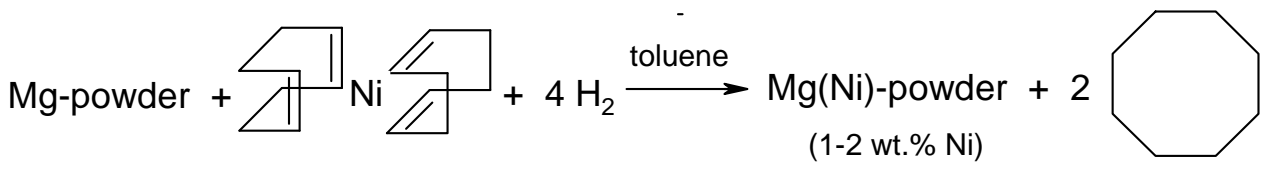


Figure 2. 1000 cycle test of $\mathrm{Ni}$-doped $\mathrm{MgH}_{2}$, time for a full cycle $3 \mathrm{~h}$.

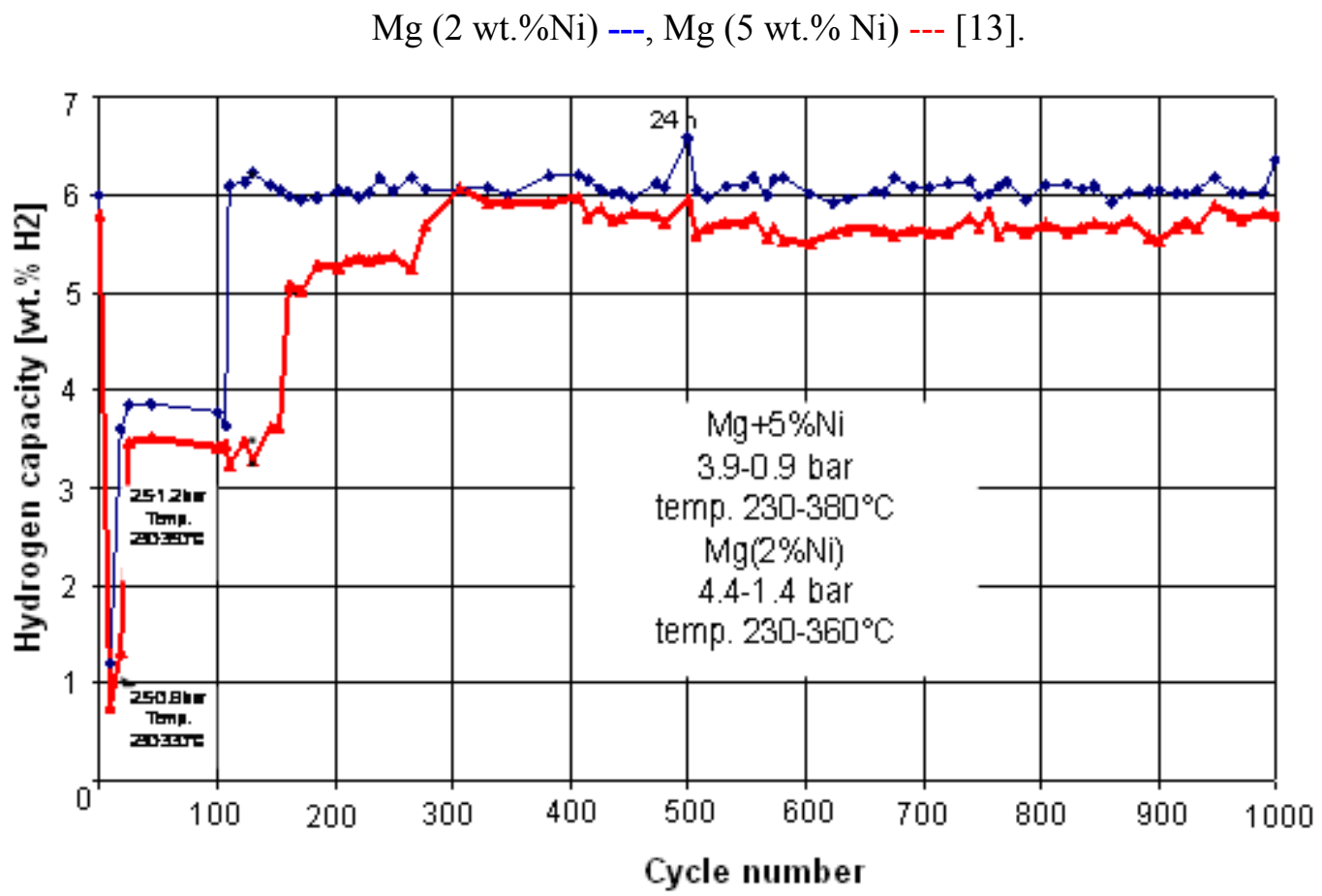

As already mentioned (Equation 2), hydrogen is liberated in the endothermic process of feeding heat $\left(75 \mathrm{~kJ} \mathrm{~mol}^{-1} \mathrm{Mg}\right)$ to $\mathrm{MgH}_{2}$, which until the reverse process of heat recovery must be temporarily stored. A heat storage system based on $\mathrm{MgH}_{2}-\mathrm{Mg}$ (Figure 3) has to be constructed as a closed system consisting of a $\mathrm{MgH}_{2}$ pressure container and an additional pressure container for the temporary storage of the displaced hydrogen (Part A). As schematically represented (Figure 3, Part A), the magnesium hydride container can be designed so to be much smaller than the pressure container for gaseous hydrogen, because of the much higher hydrogen concentration in the form of magnesium hydride. In the form of $\mathrm{MgH}_{2}$ hydrogen attains a concentration corresponding to a hydrogen pressure of $700-$ 800 bar. Up to $\sim 150{ }^{\circ} \mathrm{C} \mathrm{MgH}_{2}$ has only a very low dissociation pressure, which means that hydrogen storage in this form is comparably a secure form for hydrogen storage.

In comparison to the first version (Figure 3, Part A), a much more compact construction can and has been realized, when for the temporary storage of hydrogen in place of a pressure container is applied an at low temperature hydrogen absorbing alloy (Figure 3, Part B) which with hydrogen forms a socalled low temperature (LT) metal hydride. A LT hydride is typically a hydride on Fe-Ti or La-Nibasis [14] or, in future possibly on alanate basis [15].

Using LT hydrides for temporary storage of hydrogen, hydrogen is available at ambient or even below ambient tremperature. Apart from the compact construction, such a heat store (Figure 3, Part B) includes possibilities which are of great importance for the rational use of solar and other energy sources:

- absorption of hydrogen by the LT-alloy produces LT-heat (f.i. $30-70{ }^{\circ} \mathrm{C}$ ) which is typically $\approx 1 / 3$ of the $\mathrm{MgH}_{2}$ heat amount $\left(75 \mathrm{~kJ} \mathrm{~mol}^{-1}\right)$; this waste heat can be used for example for warm water supply; 
- the desorption of hydrogen from the side of the LT hydride takes place with withdrawal of heat from the surroundings, that is with production of cold, that can be used for production of ice or for climatisation.

- altogether a closed circular system of two (or more) conjoined reversible metal hydride systems which operate at different temperature levels represent a so-called hydride chemical heat pump, which is applicable for different types of heat and energy transformations [16].

Figure 3. Schematical representation of construction of $\mathrm{MgH}_{2} / \mathrm{Mg}$ heat stores. Part $\mathrm{A}$ : temporary storage of hydrogen in a pressure container; part B: temporary storage of hydrogen in a low-temperature metal hydride.

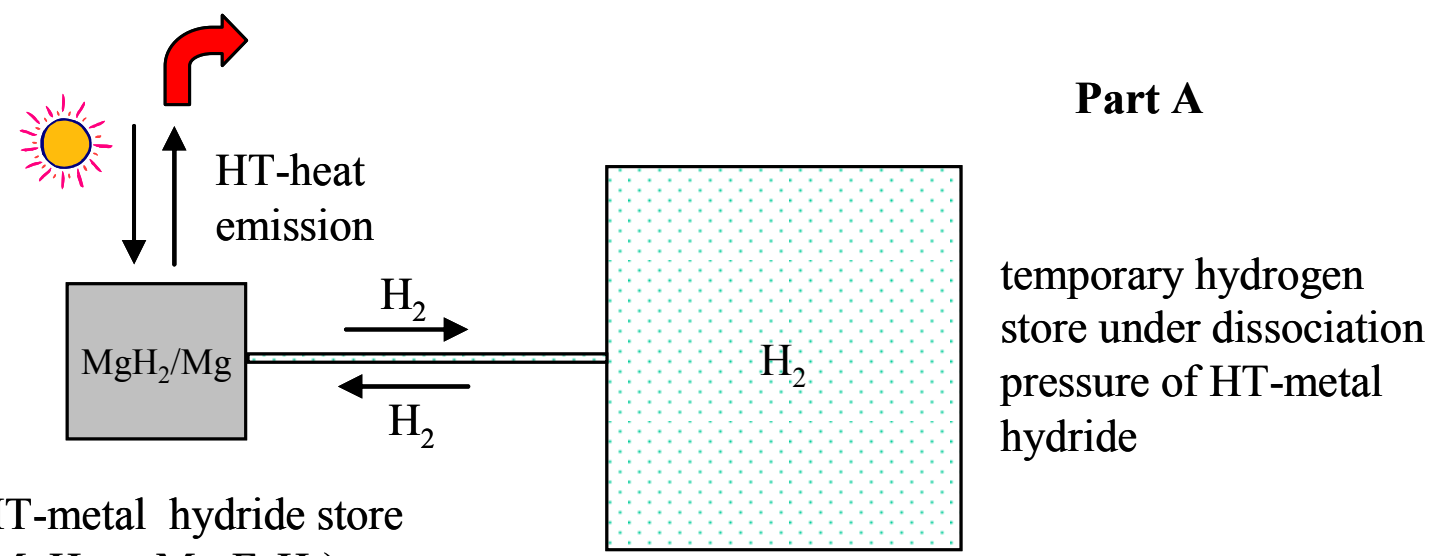
$\left(\mathrm{MgH}_{2}\right.$ or $\left.\mathrm{Mg}_{2} \mathrm{FeH}_{6}\right)$

\section{Part B}

energy flux see above
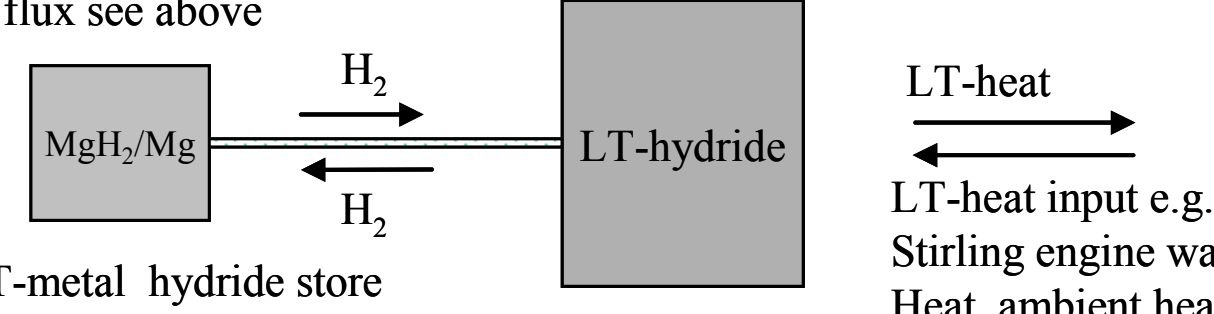

HT-metal hydride store Stirling engine waste $\left(\mathrm{MgH}_{2}\right.$ or $\left.\mathrm{Mg}_{2} \mathrm{FeH}_{6}\right)$ Heat, ambient heat

$\mathrm{HT}=$ high temperature

LT $=$ low temperature

\section{Experimental results concerning the $\mathrm{MgH}_{2}-\mathrm{Mg}$ system}

\subsection{A process steam generator $[17,18]$}

In the following three installations which are designed for different fields of application and which have been realized as laboratory prototypes are described. These were primarily engineering tasks which were tackled at first by engineers by mathematical modelling (simulations) and calculations.

Unlike engineers, chemists prefer an experimental approach. In this sense the first experimental heat accumulator on magnesium hydride basis was built and tested in our institute. The facility for the production of the process steam was installed in the pilot plant of the institute and was in operation 
during $1 \frac{1}{2}$ years. In this connection the heat transfer problems within the hydride bed (heat pipe effect) was also investigated. The process steam generator is schematically represented in Figure 4, the isolated cylindric steel pressure vessel is filled with $14.5 \mathrm{~kg}$ of $\mathrm{Ni}$-doped $\mathrm{Mg}$-powder.

Figure 4. The process steam generator based on $\mathrm{MgH}_{2}[17,18]$.

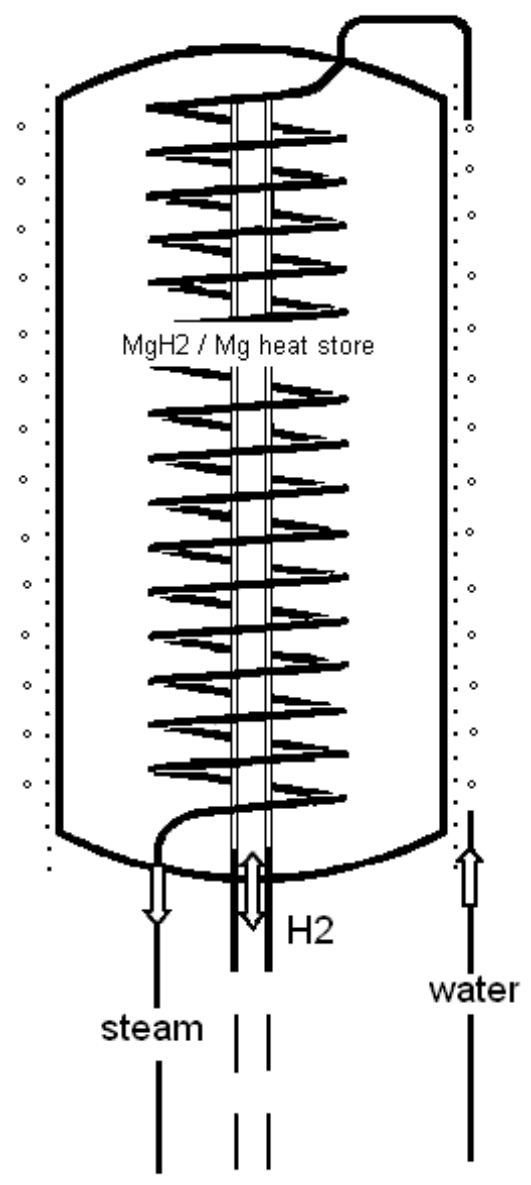

In the center of the vessel is installed a sintered metal tube for supply and removal of hydrogen. Around the vessel is wound a steel tube which is connected to a source for pressurized water. The tube is further lead into the inner of the vessel where it is helically embedded in the $\mathrm{MgH}_{2} / \mathrm{Mg}$ bulk. Hydrogenation of the Ni-doped storage material is carried out directly in the pressure vessel. For heat desorption the pressure vessel is electrically heated from outside, resulting in $\mathrm{MgH}_{2}$ dissociation. The hydrogen which escapes is temporary stored in a bunch of six commercial hydrogen pressure containers. As soon as the heating is interrupted and the temperature of the heat accumulator begins to decrease the hydrogen flows back from the pressure containers to the $\mathrm{Mg} / \mathrm{MgH}_{2}$ vessel where the HT heat is regenerated and produces in the spiral tube superheated water vapor. Some technical data about the heat store unit are given in the Table 2.

The heat accumulator had the ability to produce $4 \mathrm{~kW}$ of heat, up to $90 \%$ capacity at the same temperature level. A coupled unit of a $\mathrm{MgH}_{2} / \mathrm{Mg}$ heat store with a hydrogen pressure container (Figure 3, Part A) can also serve as a heat buffer for intermittent HT heat sources. 
Table 2. Technical Data of the $\mathrm{MgH}_{2}$-Heat Store Unit [17, 18].

\begin{tabular}{|c|c|}
\hline Amount of storage material & $14.5 \mathrm{~kg}$ \\
(Ni-doped Mg) & \\
Volume of the pressure vessel & $19.4 \mathrm{dm}^{3}$ \\
Weight of the pressure vessel & $26 \mathrm{~kg}$ \\
Bulk density & $0.75 \mathrm{~g} \mathrm{~cm}^{-3}$ \\
Maximum operational pressure & $50 \mathrm{bar}$ \\
Maximum operational temperature & $450{ }^{\circ} \mathrm{C}$ \\
Total weight & $40 \mathrm{~kg}$ \\
Amount of stored heat / total weight & $0.25 \mathrm{kWh} \mathrm{kg}^{-1}$ \\
Maximum power output & $4 \mathrm{~kW}^{-1}$ \\
Amount of water to be vaporized at the power & $6 \mathrm{~kg} \mathrm{~h}^{-1}$ \\
output of $4 \mathrm{~kW}$ & \\
Maximum steam temperature & $\mathrm{ca} .400{ }^{\circ} \mathrm{C}$ \\
Maximum steam pressure & $40 \mathrm{bar}$ \\
\hline
\end{tabular}

\subsection{A model of a thermochemical solar power plant $[1,8,11,13,19,20]$}

The $\mathrm{MgH}_{2} / \mathrm{Mg}$-heat accumulator, first used to demonstrate the feasibility for production of "process vapor", is clearly applicable for storage of industrial heat and at this temperature level $\left(350-450{ }^{\circ} \mathrm{C}\right)$ of solar heat in particular. According to the "solar concept", the combination of a solar-thermal power generator with a thermochemical $\mathrm{MgH}_{2}$ heat accumulator should enable generation of power also in the absence of sunshine, that is after sundown and during the passage of clouds. Within the frame of a publicly sponsored joint project between the both Max-Planck-Institutes in Mülheim, the IKE Institute of the Stuttgart University and the HTC Solar Company in Lörrach a first model of a small solar power station was built. Figure 5 shows a cross section of the installation. The main components were a "fixed focus concentrator" for solar radiation [11], a cavity radiation receiver, a heat pipe system for heat transfer, a Stirling engine, a $\mathrm{MgH}_{2}$ store, a hydrogen pressure or LT hydride store. For supply of the whole installation with solar heat a solar mirror collector with $6.5 \mathrm{~m}^{2}$ area of a light weight type construction was built. The concentrated solar heat is used to drive the Stirling engine and produce power. Simultaneously, a more or less part of the solar heat is absorbed by the $\mathrm{MgH}_{2}$ heat store and the released hydrogen streams in the pressure container or, alternatively, in the LT hydride store. In periods without or weak solar irradiation the $\mathrm{MgH}_{2} / \mathrm{Mg}$ system cools down and the hydrogen flows back to the $\mathrm{MgH}_{2}$ store and produces there high temperature heat and via Stirling engine electric power. The model of the solar power plant was tested under laboratory [10] and in limited extent also under solar test field conditions [11] and in this way the ability of the system to function was established. Shortcomings of the installation were realized and the measures to address them proposed. 
Figure 5. Cross section of the model of the solar power station, with $\mathrm{MgH}_{2}$ heat storage units and fix-focus solar concentrator.

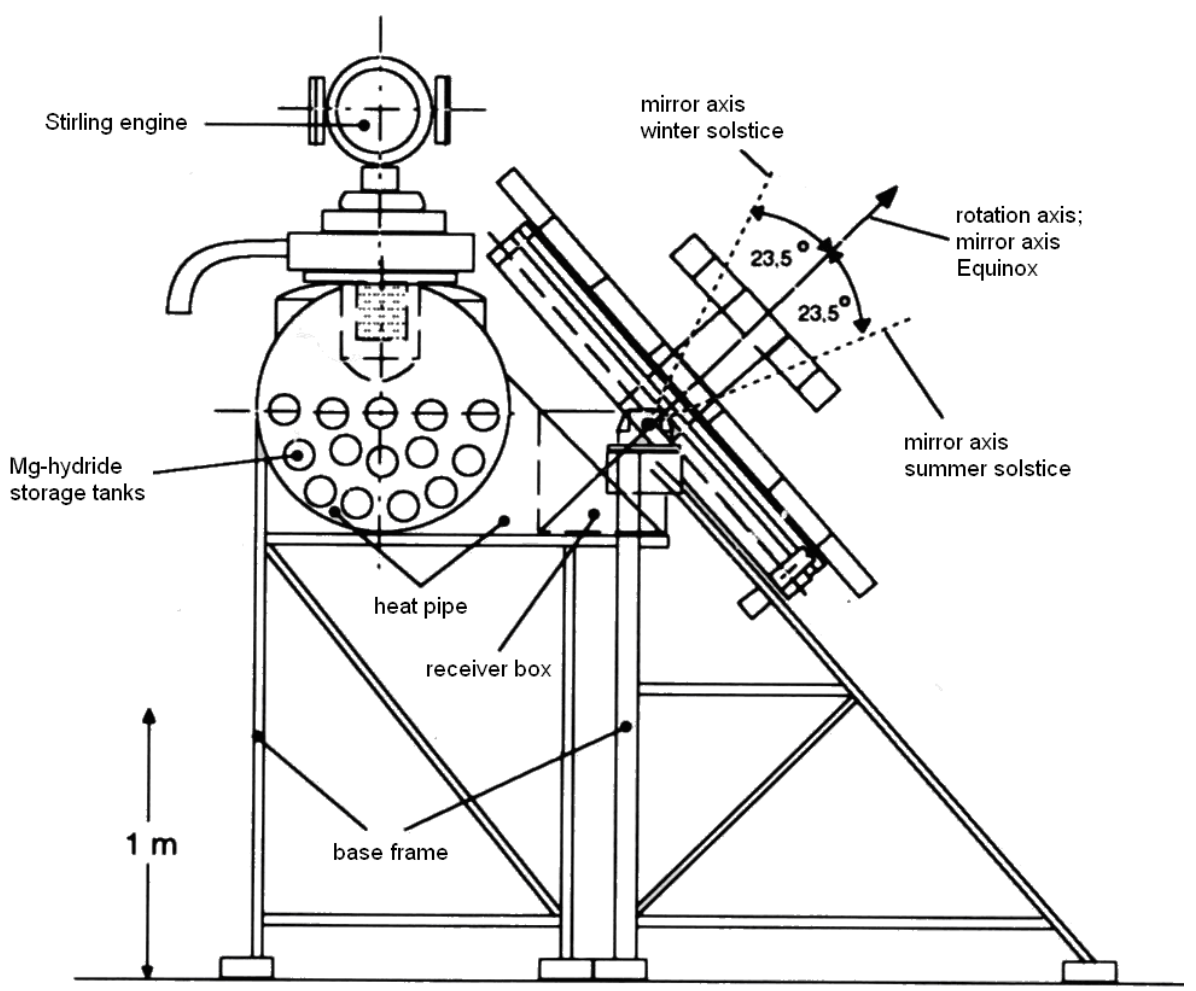

\subsection{A solar cooking- and cooling-device $[12,19]$}

As a third example for the magnesium hydride application for heat storage and transformation a laboratory model of a solar cooking-and-cooling device was built. The device consists of a $\mathrm{MgH}_{2}$-heat store unit filled with $4.4 \mathrm{~kg}(\sim 3 \mathrm{KWh}$ heat) of the Ni-doped Mg-material and equipped with a cooking plate. The unit is linked to a LT metal hydride store unit with $\sim 30 \mathrm{~kg}$ of a LT metall alloy $\left(\mathrm{MmNi}_{4.22} \mathrm{Fe}_{0.78}\right)$ coupled to a refrigerator and a water reservoir. As a cooling cabinet a commercial ice-box of $113 \mathrm{~L}$ capacity is used. The solar mirror in this case has an area of $2.5 \mathrm{~m}^{2}$ and is made out of a fibrous plastic material.

During solar irradiation hours solar heat is concentrated by means of the fixed-focus concentrator and directly used for cooking. Simultaneously, hydrogen from the $\mathrm{MgH}_{2}$-store is desorbed and absorbed in the LT alloy, thus performing the task of heat storage. The LT heat of $30-40{ }^{\circ} \mathrm{C}$ is absorbed by a water reservoir. In order to be able to cook in the absence of solar irradiation the hydrogen is allowed to stream in the reverse direction, so that the heat of $\mathrm{MgH}_{2}$ formation provides heat for cooking. During the hydrogen desorption from the LT hydride, the desorption heat is removed from the surroundings and the resulting cold with the help of a water-glycol circle system is transferred to the ice-box in which ice is produced.

A complete cycle of an experimentally performed cooking- and cooling process is described in the following. At the beginning of such a cycle hydrogen is located in the LT hydride store. Upon opening of the valve between the two stores, the hydrogen streams to the HT-store resulting in a heat evolution of around $300{ }^{\circ} \mathrm{C}$ which remains during 5-6 h at this level and is usable for cooking. At the same time 
the LTH store itself cools down to $-10{ }^{\circ} \mathrm{C}$; ice is formed in the ice-box and the temperature there remains at about $0{ }^{\circ} \mathrm{C}$. In this time $0.9 \mathrm{KWh}$ of cold are produced and $35 \%$ of this amount are allotted for the production of ice. After a rest of $7 \mathrm{~h}$ during the night, during which the hydrogen supply is disconnected, through solar irradiation, at $350-450{ }^{\circ} \mathrm{C}$, hydrogen is displaced from $\mathrm{MgH}_{2}$ and absorbed in the LT alloy with formation of warm water $\left(30-40{ }^{\circ} \mathrm{C}\right)$. The device is now ready for a new cookingcooling cycle. Laboratory tests were satisfactory, but solar (field) tests have not yet been done. As operational areas can be envisaged regions with a lot of sunshine but without energy infrastructure. Without any consumption of fuels or electric power it should be possible to cook and to refrigerate food at any day or night time.

\section{Ni-doped versus undoped $\mathrm{MgH}_{2}-\mathrm{Mg}$ materials for high temperature heat or hydrogen storage [21]}

The design and construction of the above described appliances for energy and heat storage on $\mathrm{MgH}_{2} / \mathrm{Mg}$ basis are more or less tasks for engineers. For chemists there still remains the challenge of improving the properties of metal hydride storage materials and to develop new ones. So, for instance, the question arises which is the highest application temperature level for functioning of $\mathrm{MgH}_{2} / \mathrm{Mg}$ heat storage system. The question is of great importance, because according to the Carnot principle the efficiency of heat engines - be they small Stirling engines or steam turbines - increases with the temperature level of the fed heat. In order to remain with our example: the process steam of $500{ }^{\circ} \mathrm{C}$ is more efficient for the production of power than the same heat quantity at $400{ }^{\circ} \mathrm{C}$ or lower. If under this aspect we look again at temperature dependence of the $\mathrm{MgH}_{2}$ dissociation pressure (Figure 1), it can be seen that at the temperature of, f.i. $500{ }^{\circ} \mathrm{C}$, the hydrogen pressure in the system is around 100 bar. Results of a 650 cycle test with mechanically Ni-doped Mg-powder (4 wt.\%) under severe conditions are shown in Figure 6 [21].

Figure 6. A 650 cycle test performed with mechanically Ni-doped (4 wt.\%) 270 mesh Mg powder, demonstrating reversible and irreversible hydrogen capacity losses under severe conditions; —*- and - - 45 and 135 min hydrogenation times, respectively [21].

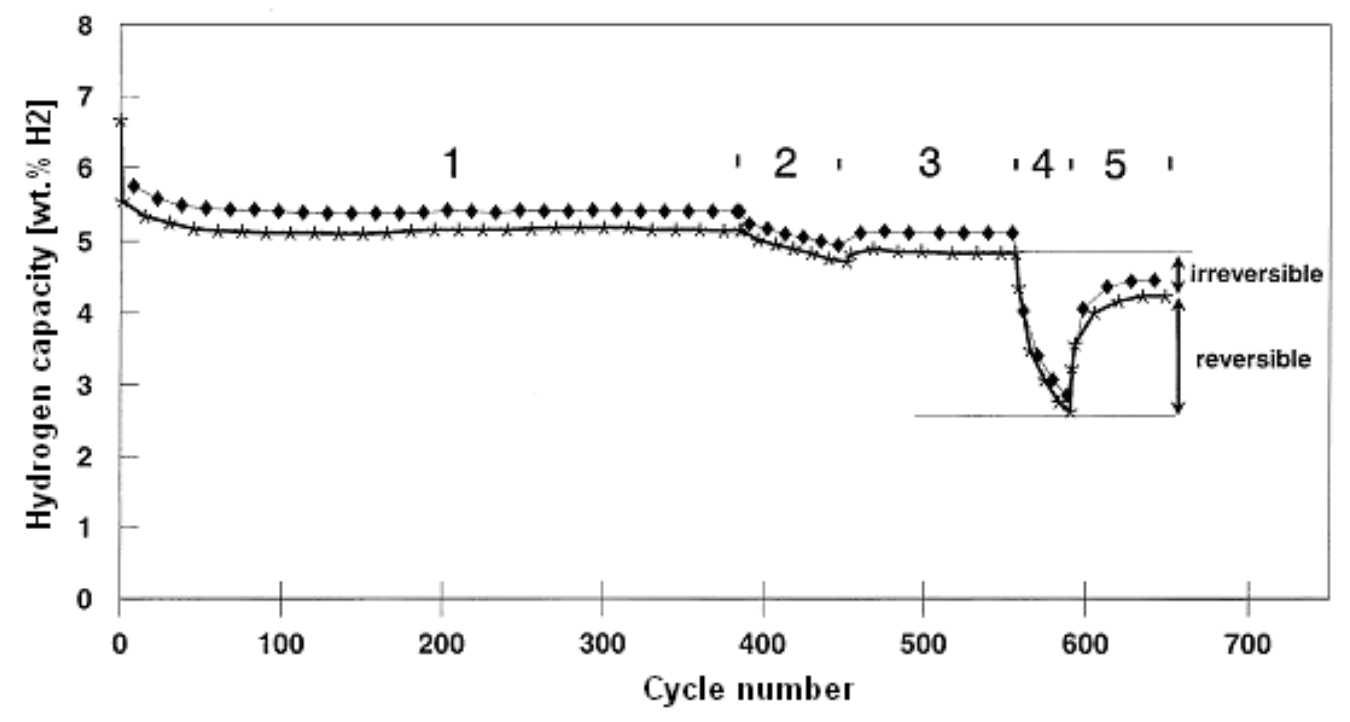


Under a high dehydrogenation temperature (section $2,480{ }^{\circ} \mathrm{C}$ ) the hydrogen capacity and with it, the amount of stored heat, decreases. An investigation of this phenomenon showed that a part of these capacity losses can be recovered under milder conditions (Sections 2/3, 4/5, "reversible capacity losses"). A part of the capacity losses, however, is permanent (Sections 1/3, 3/5, "irreversible capacity losses"). Additionally, it could be shown that capacity losses upon cyclisation are higher with Nidoped material than with undoped $\mathrm{Mg}$-powder. The consequence is therefore that for heat storage at a high temperature level $\left(>\sim 440^{\circ} \mathrm{C}\right)$, it is of advantage to use plain $\mathrm{Mg}$-powder in place of a Ni-doped one. The cause for this fall-off in performance at higher temperatures, as we presently know it, is a morphological one - namely the sintering of $\mathrm{Mg}$ particles at temperatures above $450{ }^{\circ} \mathrm{C}$, which is more pronounced in a two $(\mathrm{Mg}-\mathrm{Ni})$ than in an one component system $(\mathrm{Mg})$ [21].

\section{The Mg-Fe-H system and its potential for thermochemical thermal energy storage [22]}

\section{1. $\mathrm{Mg}_{2} \mathrm{FeH}_{6}$ as reversible ternary hydride system}

A way out of the dilemma discussed in Section 4 was to look for alternative metal hydride/metal systems in which such sintering phenomena do not occur. To overcome this problem magnesium iron hydride $\mathrm{Mg}_{2} \mathrm{FeH}_{6}$ can be used for heat storage. The compound was discovered and the structure elucidated in 1984 by Yvon et al. after heating of 2:1 mixtures of $2 \mathrm{Mg}$ and Fe powders at $450{ }^{\circ} \mathrm{C}$ under 20-120 bar $\mathrm{H}_{2}$ pressure [23].

Figure 7. Crystal unit cell of $\mathrm{Mg}_{2} \mathrm{FeH}_{6}$; $\mathrm{Mg}$-atoms are shown in blue, Fe-atoms are located in the centers of the octahedrons.

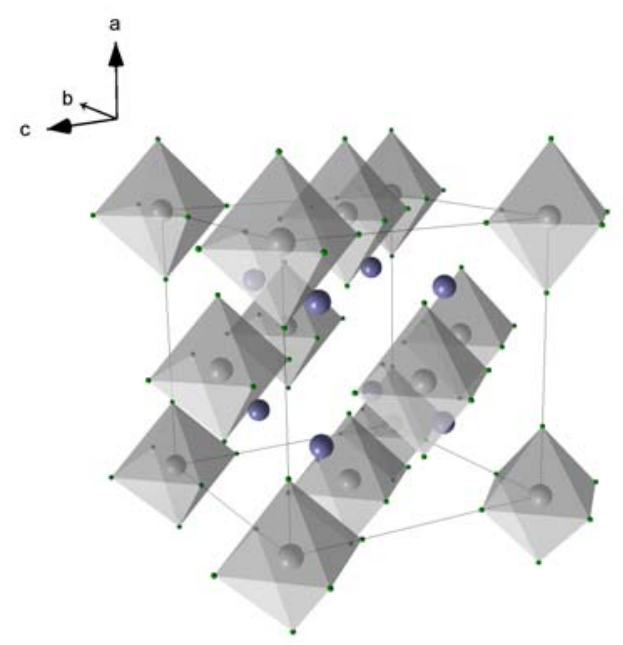

As it can be seen in Figure 7, $\mathrm{Mg}_{2} \mathrm{FeH}_{6}$ is composed of $\mathrm{Mg}^{2+}$ cations and $\mathrm{FeH}_{6}{ }^{4-}$ anions in the form of octahedrons. In the center of the octahedrons is located a Fe atom, which is surrounded by six covalently bound $\mathrm{H}$ atoms. Alternatively to the high pressure method, $\mathrm{Mg}_{2} \mathrm{FeH}_{6}$ can be synthesized by reactive mechanical alloying of $\mathrm{Fe}$ and $\mathrm{Mg}$ elemental powders in a hydrogen atmosphere at room temperature [24-26]. The gravimetric hydrogen content of $\mathrm{Mg}_{2} \mathrm{FeH}_{6}$ is $5.5 \mathrm{wt} . \%$. The volumetric hydrogen density reaches $150 \mathrm{~kg} \mathrm{~m}^{-3}$ which is double of the density of liquid hydrogen $\left(70 \mathrm{~kg} \mathrm{~m}^{-3}\right)$. 
The advantage of $\mathrm{Mg}_{2} \mathrm{FeH}_{6}$ as a heat storage material in comparison to $\mathrm{MgH}_{2}$ (Table 3) is its higher stability and hence a lower hydrogen dissociation pressure (Figure 8). So, for example, the dissociation pressure of $\mathrm{Mg}_{2} \mathrm{FeH}_{6}$ at $500{ }^{\circ} \mathrm{C}$ ( 66 bar) - is about $1 / 3$ lower than that of $\mathrm{MgH}_{2}$ at the same temperature (100 bar). This gives for the construction of pressure containers for $\mathrm{Mg}_{2} \mathrm{FeH}_{6}$ an advantage versus containers for $\mathrm{MgH}_{2}$.

Table 3. Comparision of important values for heat storage using $\mathrm{MgH}_{2}$ and $\mathrm{Mg}_{2} \mathrm{FeH}_{6}$ [22].

\begin{tabular}{|l|c|c|}
\cline { 2 - 3 } \multicolumn{1}{c|}{} & $\mathbf{M g \mathbf { H } _ { 2 }}$ & $\mathbf{M g}_{\mathbf{2}} \mathbf{F e H}_{\mathbf{6}}$ \\
\hline Reaction enthaply $\Delta \mathrm{H}\left[\mathrm{kJ} \mathrm{mol}{ }^{-1}\right]$ & 74 & 77.4 \\
Hydrogen content calc. [wt.\%] & 7.66 & 5.47 \\
Hydrogen content expt. [wt.\%] & 6 & 5 \\
Theoretical density of the hydride $\left[\mathrm{g} \mathrm{cm}^{-3}\right]$ & 1.42 & 2.74 \\
Experimentally realized density $\left[\mathrm{g} \mathrm{cm}^{-3}\right]$ & 0.8 & 1.22 \\
Heat storage density (calc. weight) $\left[\mathrm{kJ} \mathrm{kg}^{-1}\right]$ & 2,814 & 2,106 \\
Heat storage density (expt. weight) $\left[\mathrm{kJ} \mathrm{kg}^{-1}\right]$ & 2,204 & 1,921 \\
Heat storage density (calc. volume) $\left[\mathrm{kJ} \mathrm{dm}^{-3}\right]$ & 3,996 & 5,768 \\
Heat storage density (expt. volume) $\left[\mathrm{kJ} \mathrm{dm}^{-3}\right]$ & 1,763 & 2,344 \\
\hline
\end{tabular}

Figure 8. Temperature dependence of the dissociation pressure of $\mathrm{Mg}_{2} \mathrm{FeH}_{6}$ in comparision with that of $\mathrm{MgH}_{2}$ [22].

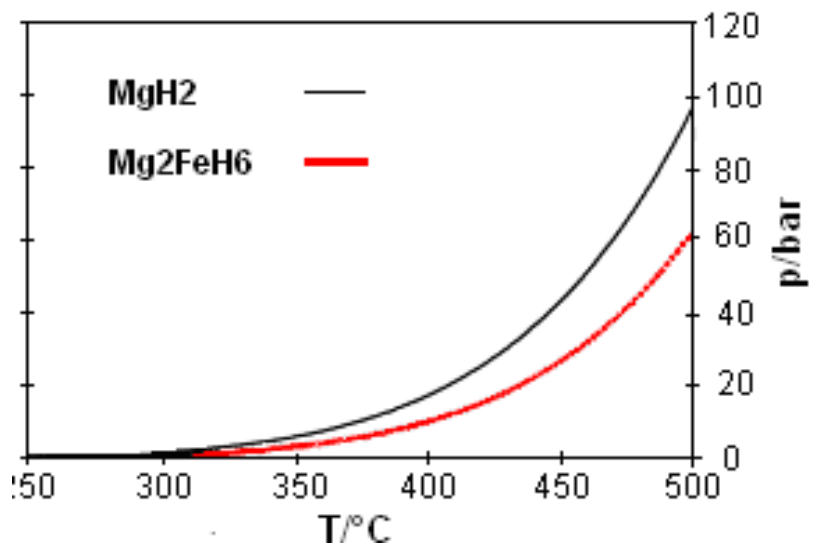

Numerous cycle tests done with the $\mathrm{Mg}-\mathrm{Fe}-\mathrm{H}$ system prove that the system is superior under high temperature and pressure conditions with respect to cycle stability in comparison to the pure $\mathrm{MgH}_{2}-\mathrm{Mg}$ system (Figure 9, top) [22]. While the latter system under different HT conditions already looses capacity after 200-250 cycles (due to sintering), the Mg-Fe-H-systems, under comparable conditions, show no signs of loss of capacity and reaction rates even after 600 or more cycles. Even under very severe conditions (510-590 ${ }^{\circ} \mathrm{C} / 138-149$ bar) cycle stabilities with a capacity of more than $5 \mathrm{wt} . \% \mathrm{H}_{2}$ are achieved. Interestingly, the improved cycle stability has been shown to exist also using less than stoichiometric amounts of Fe with respect to $\mathrm{Mg}$ (Figure 9, bottom). In view of the possible technical application of these systems for heat storage in future especially of solar heat in the temperature region 
around $500{ }^{\circ} \mathrm{C}$ or higher, this finding appears to be of importance [22]. However, further investigation of cycling properties of the mixed $\mathrm{MgH}_{2} / \mathrm{Mg}-\mathrm{Mg}_{2} \mathrm{FeH}_{6} / 2 \mathrm{Mg}$ Fe hydride sytems is necessary.

Figure 9. Hydrogen storage capacity of $\mathrm{MgH}_{2}, \mathrm{Mg}_{2} \mathrm{FeH}_{6}$ (top) and of the mixed $\mathrm{Mg}_{2} \mathrm{FeH}_{6}$ $\mathrm{MgH}_{2}$ system [22]. (Conditions for re/dehydrogenations: $482 / 533{ }^{\circ} \mathrm{C}, 80 / 86$ bar, $1.5 / 1.5 \mathrm{~h}$ ).
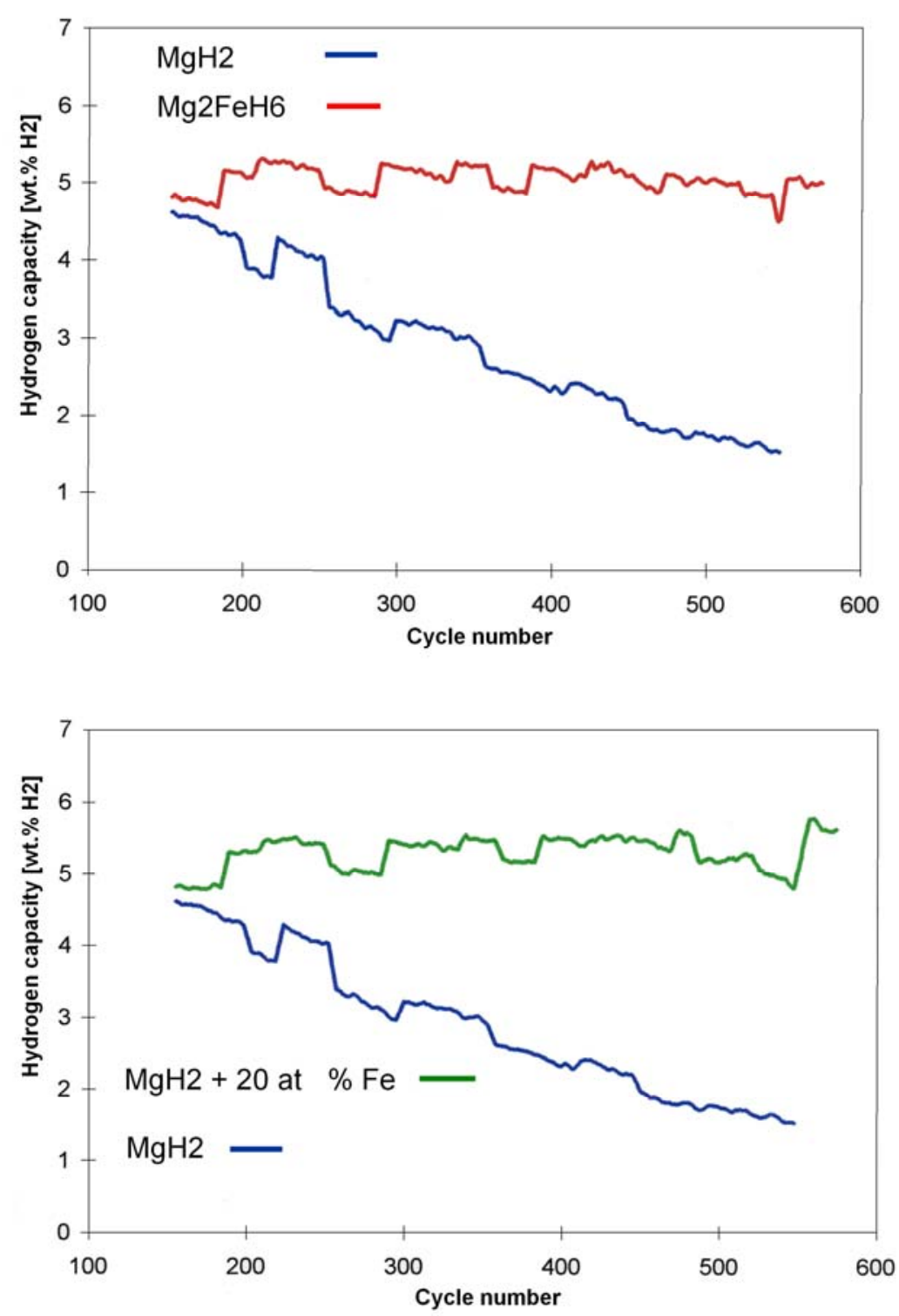

\subsection{Electron microscopy investigations of the $\mathrm{Mg}_{2} \mathrm{FeH}_{6}$ materials}

The cause for the improvement of thermochemical storage properties of the $\mathrm{Mg}-\mathrm{Fe}-\mathrm{H}$ system with respect to the $\mathrm{MgH}_{2}$ system could be partially elucidated via electron microscopy investigations on $\mathrm{Mg}-\mathrm{Fe}-\mathrm{H}$ samples in the hydrogenated and dehydrogenated state. Raster electron- microscopy images of the starting Fe and $\mathrm{Mg}$ powders (Fe 5-10 $\mu \mathrm{m}$ and $\mathrm{Mg}$ particles 50-100 $\mu \mathrm{m}$ ) and of $\mathrm{Mg}_{2} \mathrm{FeH}_{6}$ after 600 hydrogenation/dehydrogenation cycles at high temperatures are shown in Figures 10a-c. A high resolution transmission electron microscopy (TEM) micrograph of $\mathrm{Mg}_{2} \mathrm{FeH}_{6}$ is reproduced in Figure 11 (top). At 1:500,000 magnification one can already perceive the atomic net plains of the 
crystalline magnesium-iron hydride. The material is perfectly homogeneous. On the lower part of the Figure (Figure 11, bottom) can be seen a TEM photo of the dehydrogenated material: in this case black and colorless regions can be discerned. By energy dispersive X-ray (EDX) analyses it could be proved that the black regions are almost pure iron and the colorless transparent ones are pure magnesium. Upon each dehydrogenation the two metals separate from each other.

Figure 10. Raster electron images from top to the bottom: a) Fe-metal, b) Mg-flakes, c) $\mathrm{Mg}_{2} \mathrm{FeH}_{6}$ after 600 cycles.

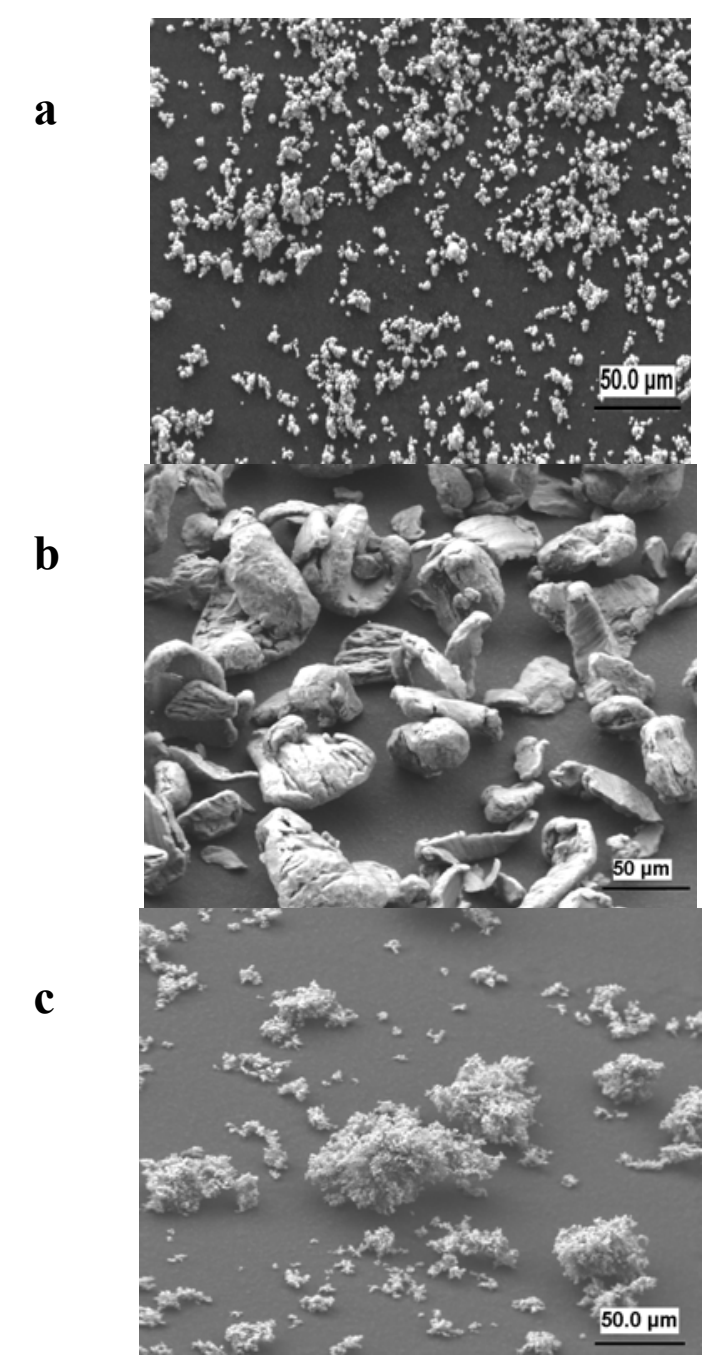

The size of the regions are in the range of 20-50 $\mathrm{nm}$. Apparently, due to this extremely fine dispersion it is possible that after each hydrogenation step the homogeneous $\mathrm{Mg}_{2} \mathrm{FeH}_{6}$ phase is formed. In the hydrogenation step a transfer of (probably) magnesium atoms must take place. With the help of TEM it was possible to identify different stages of $\mathrm{Mg}_{2} \mathrm{FeH}_{6}$ formation from $\mathrm{Fe}, \mathrm{Mg}$ and $\mathrm{H}_{2}$ and which takes place on the surface of Fe grains (Figure 11); for details see Ref. [22]. It appears plausible that this special circumstance - the separation of metals in two immiscible phases upon dehydrogenation and the merging to one phase upon hydrogenation - counteracts agglomeration of particles and thus, is one of the probable causes of cyclic stability. 
Figure 11. Left: HR-TEM-pictures of $\mathrm{Mg}_{2} \mathrm{FeH}_{6}$ (top) and dehydrogenated material $(2 \mathrm{Mg}+$ Fe) (bottom); right: TEM micrographs of different steps of $\mathrm{Mg}_{2} \mathrm{FeH}_{6}$ formation are recorded. Dark regions of the particles are Fe regions and the lighter consist of $\mathrm{Mg}_{2} \mathrm{FeH}_{6}$. (a) Initial stage of the $\mathrm{Mg}_{2} \mathrm{FeH}_{6}$ formation; (b) vermicular excresence of $\mathrm{Mg}_{2} \mathrm{FeH}_{6}$ out of the surface of an iron seed; (c) final stage of the $\mathrm{Mg}_{2} \mathrm{FeH}_{6}$ formation [22].
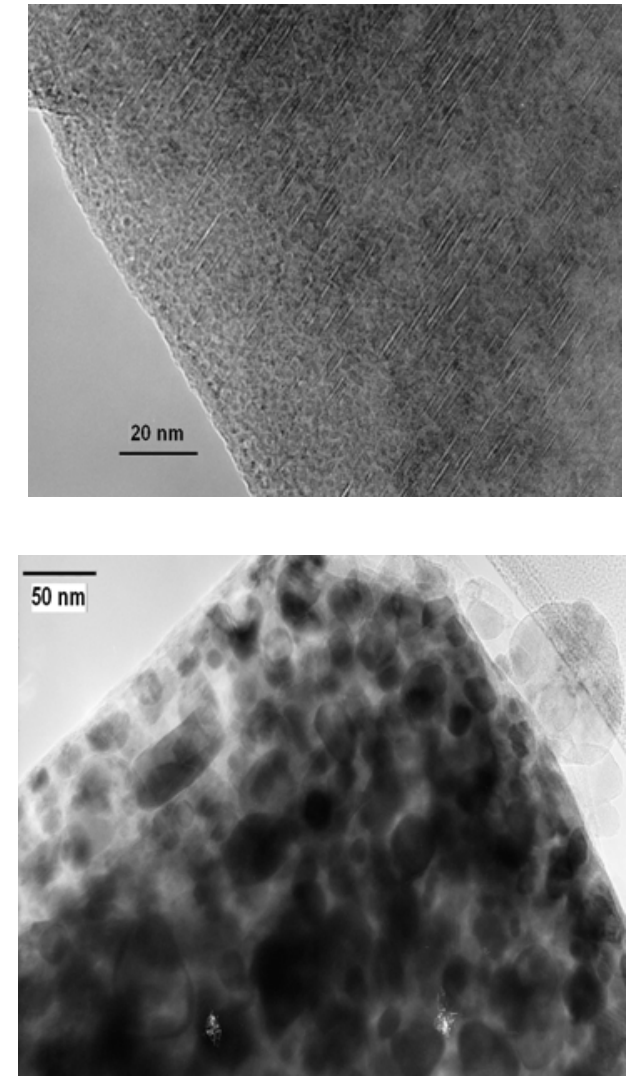

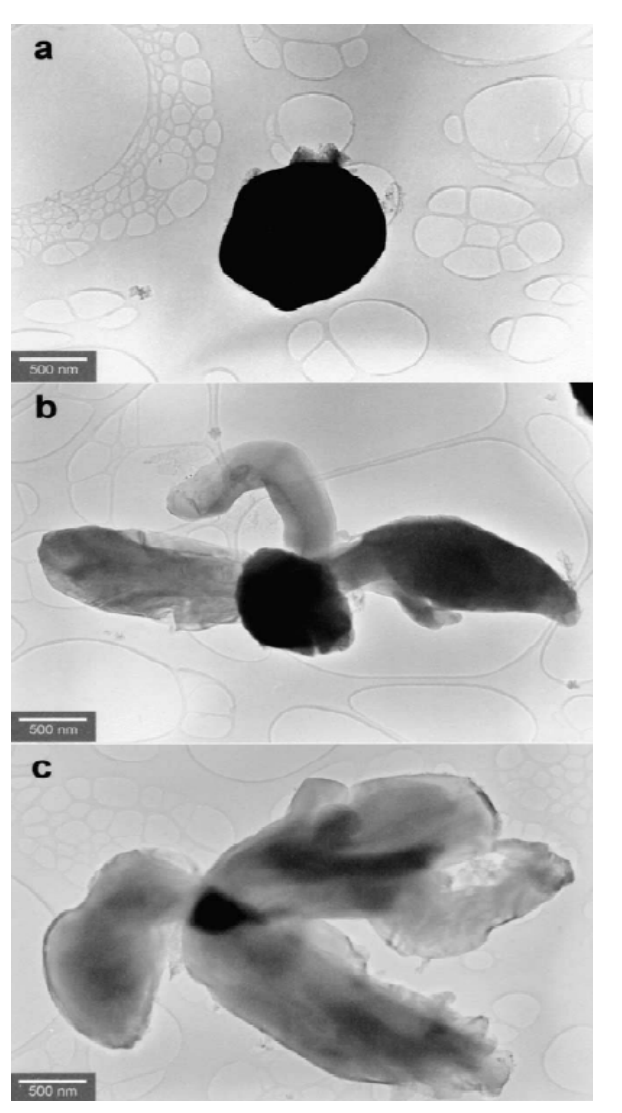

\section{A picture of a thermochemical storage of solar heat on the $\mathrm{MgH}_{2} / \mathrm{Mg}$ basis}

\subsection{Comparision of the $\mathrm{MgH}_{2} / \mathrm{Mg}$ system with the existing heat storage system of Andasol 1}

Andasol 1 is a solar thermal power plant located in Andalucia (Spain) with a $50 \mathrm{MW}$ steam turbine for electricity production. To run the plant during the dark a heat storage system is installed for additional $7.5 \mathrm{~h}$ electricity production at night. The storage system consists of two insulated storage tanks each $14 \mathrm{~m}$ high and $36 \mathrm{~m}$ in diameter (Figure 12). They are filled with 28,000 tons of a molten salt mixture of sodium and potassium nitrate. The tanks are kept at different temperatures, the cold tank at $260{ }^{\circ} \mathrm{C}$ and the hot tank at $390{ }^{\circ} \mathrm{C}$. To charge heat, the "cold" molten salt picks up heat in a heat exchanger from the $400{ }^{\circ} \mathrm{C}$ hot oil of the solar field and stores in the hot tank. For discharging the process is reversed [27]. The overall storable heat amount in this system is 1,000 MWh [28]. 
Figure 12. $50 \mathrm{MW}$ Solar power plant Andasol 1 with solar thermal energy storage system [27], photo with permission from Solar Millennium.

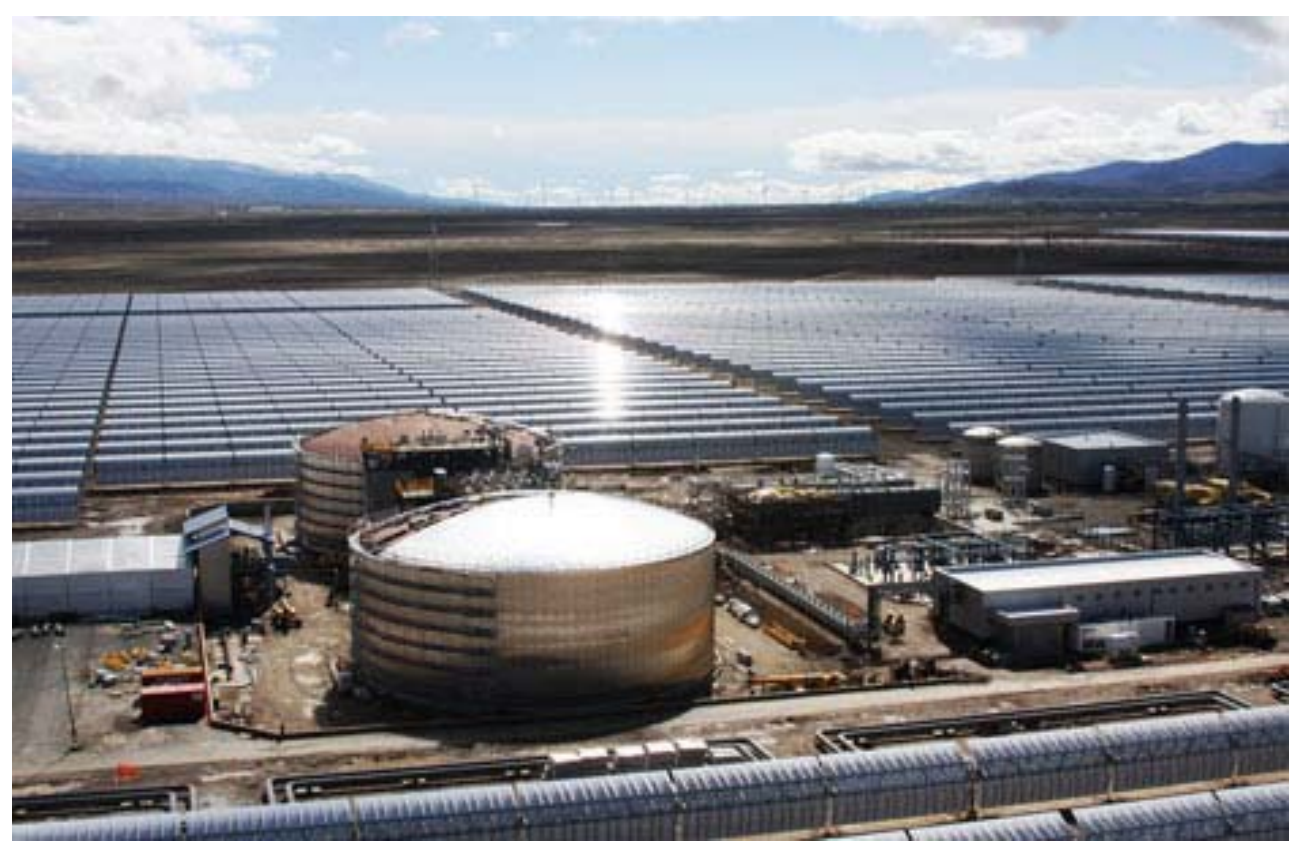

As mentioned in Section 2 the amount of heat released upon reaction of $1 \mathrm{~kg}$ of $\mathrm{Mg}$ with $\mathrm{H}_{2}$ is $0.9 \mathrm{kWh}$. Thus it can be roughly estimated that an amount of about 1,100 tons of $\mathrm{Mg}$-metal would be able to store the same amount of heat as the Andasol storage system. In addition to the storage of the $\mathrm{Mg} / \mathrm{MgH}_{2}$ mixture, a second container is necessary for the temporary storage of the hydrogen released during the dissociation of $\mathrm{MgH}_{2}$ (heat absorption Figure 3, Part A). The most simple option is the storage of hydrogen gas under own dissociation pressure of $\mathrm{MgH}_{2}$. As an example we assume here working temperatures of the heat storage between 370 and $400{ }^{\circ} \mathrm{C}$. At $370{ }^{\circ} \mathrm{C}$ the dissociation pressure of $\mathrm{MgH}_{2}$ is 10 bar and at $400{ }^{\circ} \mathrm{C}$ roughly 20 bar (Figure 1) [29]. In this pressure and temperature ranges, a simple calculation shows [30], a volume of $109,000 \mathrm{~m}^{3}$ of $\mathrm{H}_{2}$ gas resulting from decomposition of $\mathrm{MgH}_{2}$ must be stored. This sounds a lot, but, as shown below, gas storage of this order of magnitude has been standard gas technology for more than hundred years.

\subsection{Options for the storage of large volumes of hydrogen gas}

\subsubsection{Hydrogen gas storage in containers}

Natural gas storage under elevated pressures in spherical gas tanks is a widely used method. A system with a diameter up to $40 \mathrm{~m}$ and a maximum gas pressure of roughly 10 bar for natural gas has been constructed in Wuppertal, Germany and is in use since the 1950's. The volume of this storage vessel is $55,000 \mathrm{~m}^{3}$. Pipe containers are another simple method for the storage of natural gas up to pressures of 100 bar. A similar construction can also be used for the storage of hydrogen. 


\subsubsection{Hydrogen storage in gas pipelines}

Large volumes of $\mathrm{H}_{2}$ can be stored in existing hydrogen pipelines. A hydrogen pipeline can possibly be situated near a thermal solar power plant.

\subsubsection{Hydrogen gas storage in geological formations}

The storage of natural gas in underground salt caverns is also a widely used method to overcome fluctations in the demand for the gas [31]. Recently, several studies have shown that underground caverns can be used for the storage of hydrogen under elevated pressures and with extremely low leak rates $[32,33]$. Underground hydrogen storage in salt caverns is situated, f.i. in Teesside, Great Britain. The salt caverns are in a depth of $350 \mathrm{~m}$ with an overall volume of $70,000 \mathrm{~m}^{3}$. The hydrogen gas is under a constant pressure of $45 \mathrm{bar}$, which is the result of brine replacement. These values are close to those of a conceptual storage system based on a $\mathrm{MgH}_{2} / \mathrm{Mg}$ storage system for a $50 \mathrm{MW}$ solar thermal power plant. On condition is that a suitable geological formation can be found close to the power plant, but underground hydrogen storage option appears to be a cheap and simple storage method for hydrogen released from $\mathrm{MgH}_{2}$.

\section{Conclusions}

In the face of todays' urgent climate, energy and economical problems we are at present witnessing intensified planning and building of thermal solar power plants [34]. To enable the plants to function overnight storage of HT heat is necessary, which in practice usually involves storage of sensible heat by means of molten salts. As chemists we propose that, as presented in Section 6, the "thermochemical option" based on HT metal hydrides should also be taken into consideration.

On the basis of the present short overview one can easily recognize that in the research field of metal hydrides as energy storage systems both at high and low temperatures there remains yet a lot to be discovered. Currently the search for low temperature reversible hydride systems with higher than at present known $\mathrm{H}_{2}$ storage capacity, as required for heat pumps and production of cold, but first and foremost as hydrogen storage materials for fuel-cell driven cars [15, 35], seems especially worthy of efforts at the moment.

\section{Acknowledgements}

The assistance and intellectual input from B. Spliethoff and K. Schlichte over several years of research is gratefully acknowledged!

\section{References and Notes}

1. Bogdanović, B.; Ritter, A.; Spliethoff, B. Active $\mathrm{MgH}_{2}-\mathrm{Mg}$ systems for reversible chemical energy storage. Angew. Chem. Int. Ed. 1990, 29, 223-234. 
2. Beckmann, G.; Gilli, P.V. Thermal Energy Storage; Springer-Verlag: Wien, New York, 1984; p. 57, Table 2.4.

3. Buchner, H. Energiespeicherung in Metallhydriden; Springer Verlag: Wien, New York, 1982.

4. The formation of $\mathrm{NO}_{\mathrm{x}}$ in application of $\mathrm{H}_{2}$ for engines with internal combustion can be practically eliminated using lean gas mixtures $(\lambda>2)$; taken from [3], p. 126.

5. Rummel, W. Heat storage in magnesium-hydrogen system. Siemens Forsch. Entwicklungsber. 1978, 7, 44.

6. Zaluska, A.; Zaluski, B.; Ström-Olsen, J. O. Nanocrystalline magnesium for hydrogen storage. J. Alloys Comp. 1999, 288, 217-225.

7. Bogdanović, B.; Liao, S.; Schwickardi, M.; Sikorsky, P.; Spliethoff, B. Catalytic synthesis of magnesium hydride under mild conditions. Angew. Chem. Int. Ed. Engl. 1980, 19, 818-819.

8. Bogdanović, B.; Hartwig, Th.; Spliethoff, B. The development, testing and optimization of energy storage materials based on the $\mathrm{MgH}_{2}-\mathrm{Mg}$ system. Int. J. Hydrogen Energy 1993, 18, 575-589.

9. Bogdanović, B.; Kröner, M.; Wilke, G. Olefin-Komplexe des Nickels (0). Liebigs Ann. Chem. 1966, 699, 1-23.

10. Wierse, M.; Groll, M. Development, construction and testing of a thermo-chemical energy store on the $\mathrm{MgH}_{2}$ basis for solar power plants and other energy supplying systems (in German), a joint project of the German BMFT, 0328939 B, 1995; Wierse, M.; Groll, M. System performance of a solar thermal power station with a thermochemical energy storage. In Proceedings of the $11^{\text {th }}$ Hydrogen Energy Conference, Stuttgart, Germany, 23-28/7/1996, Veziroglu, T.N., Winter, C.J., Baselt, J.P., Kreysa, G., Eds.; Dechema: Frankfurt, Germany, 1996; pp. 1997-2003.

11. Kleinwächter, J.; Mitzel, M. dto., a joint project of the German BMFT, 0328993 A, 1996.

12. Steiner, D.; Wierse, M.; Groll, M. Development of a solar cooking/cooling unit with a thermochemical energy store based on metal hydrides. In Proceedings of the $11^{\text {th }}$ Hydrogen Energy Conference, Stuttgart, Germany, 23-28/7/1996; Veziroglu, T. N., Winter, C.J., Baselt, J.P., Kreysa, G., Eds.; Dechema: Frankfurt, Germany, 1996; pp. 2005-2010.

13. Reiser, A.; Bogdanović, B.; Schlichte, K. The application og Mg-based metal hydrides as heat energy storage systems. Int. J. Hydrogen Energy 2000, 25, 425-430.

14. Bowman, R.C.; Fultz, B. Metallic hydrides I: Hydrogen storage and other gas-phase applications. MRS Bulletin 2002, 27, 688-693.

15. Schüth, F.; Bogdanović, B.; Felderhoff, M. Light metal hydrides and complex hydrides for hydrogen storage. Chem. Commun. 2004, 2249-2258.

16. Dantzer, P. Metal-hydride technology: A critical review. In Hydrogen in Metals III, Topics in Applied Physics. Wipf, H., Ed.; Springer-Verlag: Berlin, Heidelberg, Germany, 1997; Volume 73.

17. Bogdanović, B.; Ritter, A. Spliethoff, B.; Straßburger, K. A process steam generator based on the high temperature magnesium hydride/magnesium heat storage system. Int. J. Hydrogen Energy 1995, 20, 811-822.

18. Straßburger, K. Wärmetransformation und thermische Energiespeicherung durch das aktive $\mathrm{MgH}_{2} / \mathrm{Mg}$-System. Thesis, University Essen: Essen, Germany 1999.

19. Bogdanović, B.; Spliethoff, B.; Ritter, A. The magnesium hydride system for heat storage and cooling. Ztschr. Physik. Chem. Neue Folge 1989, 164, 1497-1508. 
20. Bogdanović, B.; Ritter, A.; Spliethoff, B.; Straßburger, K. Development, optimisation and testing of energy storage materials on the magnesium hydride magnesium basis (in German), a joint project of the German Federal Ministry for Research and Technology (BMFT), 0328939 C, 1992.

21. Bogdanović, B.; Hofmann, H.; Neuy, A.; Reiser, A.; Schlichte, K.; Spliethoff, B.; Wessel, S. Nidoped versus undoped $\mathrm{Mg}-\mathrm{MgH}_{2}$ materials for high temperature heat or hydrogen storage. $J$ Alloys Compd. 1999, 292, 57-71.

22. Bogdanović, B.; Reiser, A.; Schlichte, K.; Spliethoff, B.; Tesche, B. Thermodynamics and dynamics of the $\mathrm{Mg}$-Fe $\mathrm{H}$ system and its potential for thermochemical thermal energy storage. $J$. Alloys Comp. 2002, 345, 77-89.

23. Didisheim, J.J.; Zolliker, P.; Yvon, K.; Fischer, P.; Schefer, J.; Gubelmann, M.;Williams, A.F. Dimagnesium Iron(II) Hydride, $\mathrm{Mg}_{2} \mathrm{FeH}_{6}$, Containing Octahedral $\mathrm{FeH}_{6}{ }^{4-}$ Anions. Inorg. Chem. 1984, 23, 1953-1957.

24. Huot, J.; Boily, S.; Akiba, E.; Schulz, R. Direct synthesis of $\mathrm{Mg}_{2} \mathrm{FeH}_{6}$ by mechanical alloying. $J$. Alloys Compd. 1998, 280, 306-309.

25. Gennari, F.C.; Castro, F.J.; Andrade Gamboa, J.J. Synthesis of $\mathrm{Mg}_{2} \mathrm{FeH}_{6}$ by reactive mechanical alloying: formation and decomposition properties. J. Alloys Compd. 2002, 339, 261-267.

26. Varin, R.A.; Li, S.; Calka, A.; Wexler, D. Formation and environmental stability of nanocrystalline and amorphous hydrides in the $2 \mathrm{Mg}$-Fe mixture processed by controlled reactive mechanical alloying (CRMA). J. Alloys Compd. 2004, 373, 270-286.

27. Fairly, P. Largest Solar Thermal Power Plant to Start Up; http://www.spectrum.iee.org/oct08/ 6851, accessed October 2008.

28. http://www.nrel.gov/csp/troughnet/pdfs/2007/martin_andasol_pictures_storage.pdf, accessed March 2007.

29. Bogdanović, B., Bohmhammel, K., Christ, B., Reiser, A., Schlichte, K., Vehlen, K., Wolf, U. Thermodynamic investigation of the magnesium hydrogen system. J. Alloys Compd. 1999, 282, 84-92.

30. The amount of 1,100 tons of $\mathrm{Mg}$, when converted into $\mathrm{MgH}_{2}$, would upon dissociation deliver $1.09 \times 10^{6} \mathrm{Nm}^{3}$ of $\mathrm{H}_{2}$ or $109,000 \mathrm{~m}^{3}$ at 10 bar pressure. Thus, for temporary storage of hydrogen a storage tank of $109,000 \mathrm{~m}^{3}$ capacity is necessary. We envisage that at the beginning of a heat storage cycle the tank is filled with 10 bar of hydrogen. Upon heating of the storage unit filled with 1,100 tons of $\mathrm{MgH}_{2}$ from 370 to $400{ }^{\circ} \mathrm{C}$, the unit, upon complete dissociation of $\mathrm{MgH}_{2}$ would release $109,000 \mathrm{~m}^{3}$ of hydrogen, which when introduced into the storage tank would result in a pressure increase from 10 to 20 bar (Figure 1). During night the heat store unit will cool down and the hydrogen will flow back to the heat store, producing there 1,000 MWh of heat at the 400 to $370{ }^{\circ} \mathrm{C}$ temperature level. The pressure in the system will drop from 20 to 10 bar, thus restoring the initial state. It should be mentioned that the described system is self-controlled, depending only of the amount of heat out- or input to the storing unit. Certainly, the presented is a very crude outline of a heat storage cycle, since during the cycle ubiquitous heat losses have to be taken into account. On the other hand, by assuming higher than at presently used working temperatures and pressures for the heat storage cycle, much smaller volumes for the hydrogen storage tank can be calculated.

31. Sedlacek, R. Underground Gas Storage in Europe. Erdöl, Erdgas, Kohle. 1999, 115, 537-540. 
32. Leighty, W. Running the world on renewables: Hydrogen transmission pipelines and firming geologic storage. Int. J. Energy Res. 2008, 32, 408-426.

33. Crotogino, F., Hamelmann, R. Wasserstoff-Speicherung in Salzkavernen zur Glättung des Windstromangebotes. 14. Symposium zur Nutzung regenerativer Energiequellen und Wasserstofftechnik, Stralsund, Germany, Nov. 2007. Energieperspektiven 2, 2008, http://www.ipp.mpg.de/ippcms/ep/ausgaben/ep200802/bilder/wasserstoff_speicher, accessed 2008.

34. http://www.solarpaces.org/News/Projects/_projects.htm, accessed 2008.

35. Züttel, A., Borgschulte, A, Schlapbach, L. (Eds.). Hydrogen as a Future Energy Carrier; WileyVCH: Weinheim, Germany, 2008.

(C) 2009 by the authors; licensee Molecular Diversity Preservation International, Basel, Switzerland. This article is an open-access article distributed under the terms and conditions of the Creative Commons Attribution license (http://creativecommons.org/licenses/by/3.0/). 